Article

\title{
Venom Proteome of Spine-Bellied Sea Snake (Hydrophis curtus) from Penang, Malaysia: Toxicity Correlation, Immunoprofiling and Cross-Neutralization by Sea Snake Antivenom
}

\author{
Choo Hock Tan ${ }^{1, *}$, Kae Yi Tan ${ }^{2}$, Tzu Shan Ng ${ }^{2}$, Si Mui Sim ${ }^{1}$ and Nget Hong Tan ${ }^{2}$ \\ 1 Department of Pharmacology, Faculty of Medicine, University of Malaya, Kuala Lumpur 50603, Malaysia; \\ debrasim@um.edu.my \\ 2 Department of Molecular Medicine, Faculty of Medicine, University of Malaya, Kuala Lumpur 50603, \\ Malaysia; kytan_kae@um.edu.my (K.Y.T.); ngtzushan@um.edu.my (T.S.N.); \\ tanngethong@yahoo.com.sg (N.H.T.) \\ * Correspondence: tanch@um.edu.my; Tel.: +603-79676685
}

Received: 11 November 2018; Accepted: 19 December 2018; Published: 23 December 2018

check for updates

\begin{abstract}
The venom proteome of Hydrophis curtus (synonym: Lapemis hardwickii) from Penang, Malaysia was investigated with nano-electrospray ionization-liquid chromatography tandem mass spectrometry (ESI-LCMS/MS) of the reverse-phase high-performance liquid chromatography (HPLC) venom fractions. Thirty distinct protein forms were identified as toxins from ten families. The three major protein families were phospholipase $\mathrm{A}_{2}$ ( $\mathrm{PLA}_{2}, 62.0 \%$ of total venom proteins), three-finger toxin (3FTX, 26.33\%) and cysteine-rich secretory protein (CRiSP, 9.00\%). PLA 2 comprises diverse homologues (11 forms), predominantly the acidic subtypes (48.26\%). 3FTX composed of one short alpha-neurotoxin (SNTX, 22.89\%) and four long alpha-neurotoxins (LNTX, 3.44\%). Both SNTX and LNTX were lethal in mice (intravenous $\mathrm{LD}_{50}=0.10$ and $0.24 \mu \mathrm{g} / \mathrm{g}$, respectively) but the $\mathrm{PLA}_{2}$ were non-lethal $\left(\mathrm{LD}_{50}>1 \mu \mathrm{g} / \mathrm{g}\right)$. The more abundant and toxic SNTX appeared to be the main driver of venom lethality (holovenom $\mathrm{LD}_{50}=0.20 \mu \mathrm{g} / \mathrm{g}$ ). The heterologous Sea Snake Antivenom (SSAV, Australia) effectively cross-neutralized the venom (normalized potency $=9.35 \mathrm{mg}$ venom neutralized per $g$ antivenom) and the two neurotoxins in vivo, with the LNTX being neutralized more effectively (normalized potency $=3.5 \mathrm{mg}$ toxin $/ \mathrm{g}$ antivenom) than SNTX (normalized potency $=1.57 \mathrm{mg} / \mathrm{g}$ ). SSAV immunorecognition was strong toward $\mathrm{PLA}_{2}$ but moderate-to-weak toward the alpha-neurotoxins, indicating that neutralization of the alpha-neurotoxins should be further improved.
\end{abstract}

Keywords: Lapemis hardwickii; immunoreactivity; alpha-neurotoxins; three-finger toxins; phospholipase $\mathrm{A}_{2}$; envenomation; neutralization

Key Contribution: An in-depth venom proteomics of Hydrophis curtus (spine-bellied sea snake) from Penang Island, Malaysia is reported and correlated with the toxicity of the major toxins, as well as their in vivo cross-neutralization using the Sea Snake Antivenom produced for Hydrophis schistosus. This study provides important insights into the diversity and variability of sea snake venom protein composition, and how antivenom manufacturing and use can be optimized.

\section{Introduction}

The Elapidae family of venomous snakes consists of approximately 369 species in $>60$ genera (www.reptile-database.org). A basal split in their phylogeny circa 10.1-24.3 Mya gave rise to the 
recent divergence of Australo-Melanesian elapids, resulting in two distinct subfamilies: (1) Elapinae, consisting of the paleogeographically-related Asian, African and American elapids; (2) Hydrophiinae, comprising the Australo-Melanesian elapids [1,2]. The Hydrophiinae represents a diverse paraphyletic clade that rapidly radiates in and around Australia, producing lineages that were well adapted to terrestrial or aquatic habitats [2]. The aquatic elapids, generally referred to as sea snakes, form a large group of marine reptiles. It comprises the basal, semi-aquatic sea kraits (Laticauda sp., 6 species) and the more derived, densely complex true sea snakes ( $>50$ species). The genus Hydrophis constitutes the core group of the true sea snakes. It is considered as a monophyletic clade by consensus today [3].

Hydrophis sea snakes live their entire lives in the water, and some of the species are often part of the by-catch of fishermen in areas where they occur. Sea snake bite typically occurs among the fishermen while removing sea snakes entangled in their fishing nets-a classic scenario described in most sea snake bite literature [4,5], although treading on a sea snake in shallow estuaries has also been reported as a cause [6,7]. In Southeast Asia, sea snake envenoming is increasingly an occupational health hazard that has expanded its threat beyond the fishing community. In this part of the world, sea snakes are a significant part of the global wildlife trade [8], where they are captured, bred and harvested for live snake parts used in the production of accessories, and for food (sea snake meat as an exotic delicacy), as well as for medicinal use (tonic soup, snake wine, gall bladder as traditional medicament). The increased human contact with sea snakes from these anthropogenic activities poses a threat to a wider community of people. Although sea snake bites are infrequently reported, envenoming is fatal, and early treatment may be missed as the bite is painless [9]. Clinically, patients envenomed by the common beaked sea snake (Hydrophis schistosus, or Enhydrina schistosa) develop neuromuscular paralysis and systemic myotoxicity complicated by acute kidney injury $[10,11]$. The pathophysiology of $H$. schistosus envenoming has been correlated with the presence of alpha-neurotoxins and basic phospholipases $A_{2}$ in the venom [12-14], while the envenomation by other sea snake species is commonly assumed to follow a similar mechanism. As sea snakes are highly adapted to their ecological niche, their venoms are thought to be "biochemically simple", with a composition that is strictly diet-driven to subdue fast-moving prey (fish). The streamlined nature of sea snake venoms and the link to their ichthyophagous dietary simplicity have been shown earlier in an extensive liquid chromatography-mass spectrometry (LC/MS) analysis of Colubroidea snake venoms [15]. Indeed, a handful of venom proteomic studies of sea snakes and a sea krait were in agreement that alpha-neurotoxins and phospholipases $A_{2}$ form the dominant proteins in these venoms [12,16-20]. The highly streamlined "minimalist" venom proteomes, however, does not limit the diversity of the toxins: the molecular subtypes, relative abundances and functionality (including toxic activities) of the venom proteins could still vary $[14,19,21,22]$. This provides the rationale for continuous investigation into the venom proteomes of different sea snake species in order to understand the intra-genus and intra-species diversity and evolution of the toxins. The knowledge will pave the path for in-depth exploration of venom antigenic properties, which is crucial for the optimization of antivenom production technique in the region [23].

Currently, the only definitive antidote treatment for sea snake envenoming is the Sea Snake Antivenom (SSAV) produced by Seqirus (previously CSL, Australia) against Hydrophis schistosus, using venom sourced from Penang Island, Malaysia. This antivenom has been shown to be effective in vitro in preventing neuromuscular depressant activity induced by the venoms of several sea snakes and a sea krait [24]. In vivo, SSAV was able to protect mice from the lethal effect of H. schistosus, Hydrophis platura, Aipysurus laevus and Laticauda colubrina venoms to various extents [12,17-19]. To elucidate the limiting factors of antivenom efficacy, the principal toxins, namely the subtypes of alpha-neurotoxins and phospholipases $\mathrm{A}_{2}$ in $H$. schistosus and L. colubrina venoms, have been further purified and tested for toxin-specific neutralization $[19,25]$. The in vivo cross-neutralization of SSAV against the venoms and principal toxins of other sea snake species that are medically relevant and widely distributed, e.g., the spine-bellied sea snake (Hydrophis curtus), remains to be further examined. 
In the Gulf of Thailand, it was reported that one of the main species involved in the catch and trade industry is the spine-bellied sea snake [8]—named for the multiple small spiny protrusion on its ventral scales over the abdominal region (Figure 1). This species was previously placed within the genus Lapemis, which is now incorporated into the core Hydrophis group, and is known as H. curtus (Shaw's sea snake) or Hydrophis hardwickii (Hardwick's sea snake), although H. hardwickii is commonly considered to be a synonym of $H$. curtus or a subspecies of $H$. curtus. Hydrophis curtus has extensive distribution form the Persian Gulf to the Indian coastline, Myanmar, Thailand, Straits of Malacca, Strait of Taiwan, South China Sea, the Philippines, Indonesia, Papua New Guinea, and northern and eastern Australia (http:/ / reptile-database.reptarium.cz/). This is also a species commonly encountered by fishermen in the western coast of Peninsular Malaya [26], as with the beaked sea snake, H. schistosus (author CHT's observation). Recently, the venom proteome of H. curtus from Australian waters (Weipa) has been reported. It shows a venom profile rich in alpha-neurotoxins, phospholipases $\mathrm{A}_{2}$ and cysteine-rich venom proteins, along with some high molecular weight proteins and a number of regulatory or cellular proteins [20]. In the present study, using a decomplexing proteomic approach, the venom proteome of $H$. curtus from Penang (Malaysia) was characterized for insights into the geographical variation of the venom. The in vivo toxicity and the antigenic properties of the major toxins of this species were also investigated, and the venom functionality was elucidated in correlation with the venom proteome. In addition, the in vivo efficacy of the heterologous antivenom, SSAV, was also examined for cross-neutralization and immunorecognition for $H$. curtus venom proteins, including the principal lethal toxins.
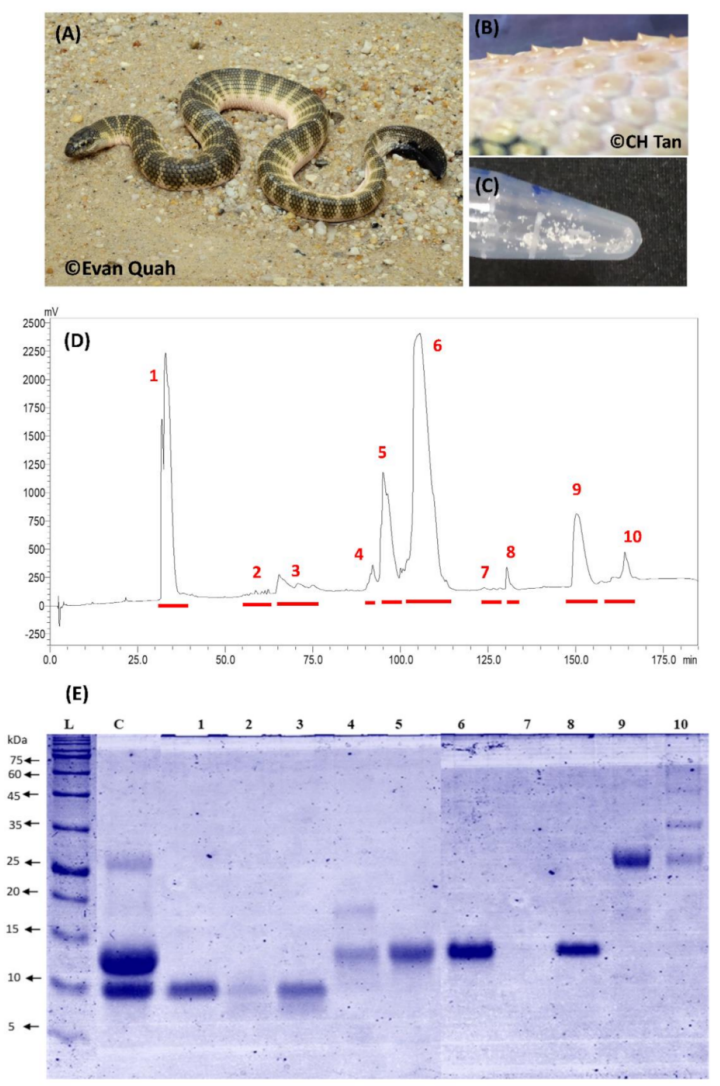

Figure 1. (A) Spine-bellied sea snake, Hydrophis curtus from Penang Island, Malaysia. (B) Protruding spine-like structures on the ventral scales of the snake. (C) Lyophilized H. curtus venom in whitish crystalline form. (D) Decomplexation of H. curtus (Penang, Malaysia) venom with C18 reverse-phase HPLC. (E) 15\% SDS-PAGE of H. curtus venom and its HPLC fractions under reducing conditions. L: Protein markers; C: Whole venom. Numbers indicate HPLC fractions. 


\section{Results}

\subsection{Decomplexation Proteomics of Penang H. curtus Venom}

H. curtus venom was resolved by $\mathrm{C} 18$ reverse-phase high-performance liquid chromatography (HPLC) into 10 protein fractions as assigned in Figure 1. Fractions 1, 5, 6 and 9 were the major fractions, constituting $>90 \%$ total venom proteins (estimation made by peaks area). SDS-PAGE showed that fractions 1-3 contained proteins of low molecular mass ( $<10 \mathrm{kDa})$, whereas Fractions 4, 5, 6 and 8 contained proteins of 12-15 kDa (Figure 1). Moderate to high molecular weight proteins eluted later (beyond $150 \mathrm{~min}$ of HPLC): Fraction 9 contained a protein of approximately $26 \mathrm{kDa}$, while Fraction 10 was heterogeneous with multiple proteins $(25-100 \mathrm{kDa})$. There was no protein band observed in Fraction 7. The SDS-PAGE of the whole venom revealed that the proteins of $12-15 \mathrm{kDa}$ formed the bulk of the venom proteins ( $\sim 60 \%$ by densitometry), followed by proteins of $<10 \mathrm{kDa}(\sim 30 \%)$ and $26 \mathrm{kDa}$ $(\sim 10 \%)$, consistent with the HPLC profile and the overall SDS-PAGE of the venom fractions (Figure 1).

\subsection{Proteome of Penang H. curtus Venom}

The HPLC fractions of venom proteins were further identified by LCMS/MS and data-mining through a non-redundant NCBI protein dataset (taxonomy: Serpentes, taxid: 8570) and an in-house venom-gland transcriptomic database. Table 1 documents the identified and categorized proteins according to the corresponding HPLC fractions. In the table, relevant information on the protein profiling, including the protein abundances (\% total venom proteins), accession numbers, protein scores and numbers of matched tryptic peptides is shown. Data generated via the tandem mass spectrometry (MS/MS) e.g., the ionic mass/charge ratios and tryptic peptide sequences, were compiled in Supplementary File Table S1.

A total of 41 distinct proteins (toxins and non-toxins) were identified from $H$. curtus venom (Table 2). The majority of the proteins identified (26 out of 41 ) were annotated to database sequences shared by the same species ( $H$. curtus or $H$. hardwickii). In total, $98.6 \%$ of the venom proteins were composed of toxins clustered into 10 families (comprising 30 identifiable toxins). Of these, phospholipase $\mathrm{A}_{2}\left(\mathrm{PLA}_{2}, 62.0 \%\right)$ dominated the proteome. Within the PLA $\mathrm{A}_{2}$ family, the acidic subtypes were more abundant than the basic subtypes (5:1 ratio). The protein abundance was followed by three-finger toxin (3FTX, 26.33\%) and cysteine-rich secretory protein (CRiSP, 9.0\%). The 3FTX proteins consisted of short neurotoxin (SNTX, one subtype) as its major component (22.89\%), while the long neurotoxins (LNTX, 3 subtypes) were less abundant (3.44\%). A variety of toxins of low abundances $(<0.5 \%$ each) were also identified, including snake venom metalloproteinase, L-amino acid oxidase, Ophiophagus venom factor, waprin, phosphodiesterase, phospholipase $\mathrm{A}_{2}$ inhibitor and phospholipase B (Figure 2). Approximately 11 non-toxin proteins or $1.4 \%$ of the venom proteins were regulatory or cellular proteins.

The proteomic profile of the Malaysian H. curtus venom (current study) was further tabulated in Table 3 in comparison with venomic data reported previously for other sea elapids. 
Table 1. Protein identification of Malaysian (Penang) Hydrophis curtus venom by ESI-LCMS/MS of C18 reverse-phase HPLC following in-solution tryptic digestion.

\begin{tabular}{|c|c|c|c|c|c|c|}
\hline Fraction & Distinct Peptides & MS/MS Search Score & $\begin{array}{c}\text { Species } \\
\text { (as Per Annotation in Database) }\end{array}$ & Database Accession $^{\text {a }}$ & $\begin{array}{c}\text { Protein Name } \\
\text { (as Per Annotation in Database) }\end{array}$ & Relative Abundance (\%) ${ }^{b}$ \\
\hline 1 & 2 & 28.12 & Hydrophis curtus & P68416 & Short neurotoxin 1 & 22.89 \\
\hline 2 & 3 & 62.47 & Hydrophis curtus & A3FM53 & Long neurotoxin 2 & 0.49 \\
\hline \multirow[t]{4}{*}{3} & 5 & 114.27 & Hydrophis curtus & Q8UW29 & Long neurotoxin 1 & 1.10 \\
\hline & 4 & 84.14 & Hydrophis curtus & A3FM53 & Long neurotoxin 2 & 1.32 \\
\hline & 2 & 40.42 & Ophiophagus hannah & Q53B58 & Long neurotoxin OH-55 & 0.33 \\
\hline & 1 & 21.62 & Ophiophagus hannah & Q53B57 & Long neurotoxin OH-56 & 0.21 \\
\hline \multirow[t]{7}{*}{4} & 5 & 92.36 & Hydrophis curtus & Q8UW31 & Acidic phospholipase $\mathrm{A}_{2} 57$ & 0.08 \\
\hline & 2 & 46.47 & Enhydrina schistosa & Unigene22561_ESM & Acidic phospholipase $A_{2} 57$ & 0.34 \\
\hline & 2 & 43.43 & Hydrophis curtus & CL4079.Contig1_HCM & Basic phospholipase $A_{2} 73$ & 0.07 \\
\hline & 2 & 35.82 & Calliophis intestinalis & CL2932.Contig3_CIM & Acidic phospholipase $A_{2} 57$ & 0.16 \\
\hline & 3 & 66.02 & Enhydrina schistosa & P00610 & Basic phospholipase $\mathrm{A}_{2}$ & 0.45 \\
\hline & 2 & 50.61 & Hydrophis curtus & Q8UW30 & Basic phospholipase $\mathrm{A}_{2} 73$ & 0.32 \\
\hline & 1 & 20.76 & Hydrophis curtus & Unigene14087_HCM & Waprin-Rha1 & 0.11 \\
\hline \multirow[t]{8}{*}{5} & 4 & 85.11 & Enhydrina schistosa & P00610 & Basic phospholipase $A_{2}$ & 2.90 \\
\hline & 3 & 64.58 & Hydrophis curtus & Q8UW08 & Basic phospholipase $A_{2}$ & 1.68 \\
\hline & 3 & 60.39 & Hydrophis curtus & Q8UW30 & Basic phospholipase $\mathrm{A}_{2} 73$ & 2.78 \\
\hline & 2 & 46.67 & Enhydrina schistosa & Unigene22561_ESM & Acidic phospholipase $A_{2} 57$ & 1.80 \\
\hline & 2 & 45.14 & Naja Naja & CL339.Contig1_NNSL & Basic phospholipase $A_{2}$ & 2.85 \\
\hline & 3 & 47.42 & Hydrophis curtus & Q8UW31 & Acidic phospholipase $\mathrm{A}_{2} 57$ & 0.48 \\
\hline & 2 & 31.85 & Bungurus caeruleus & Unigene17389_BCSL & Acidic phospholipase $A_{2} 57$ & 0.05 \\
\hline & 2 & 24.1 & Calliophis intestinalis & CL2932.Contig3_CIM & Acidic phospholipase $\mathrm{A}_{2} 57$ & 0.15 \\
\hline \multirow[t]{6}{*}{6} & 7 & 131.08 & Hydrophis curtus & Q8UW31 & Acidic phospholipase $\mathrm{A}_{2} 57$ & 28.11 \\
\hline & 2 & 46.96 & Hydrophis curtus & Q8UW08 & Basic phospholipase $\mathrm{A}_{2}$ & 0.98 \\
\hline & 2 & 42.22 & Enhydrina schistosa & P00610 & Basic phospholipase $A_{2}$ & 0.80 \\
\hline & 2 & 41.03 & Bungarus caeruleus & Unigene17389_BCSL & Acidic phospholipase $\mathrm{A}_{2} 57$ & 15.26 \\
\hline & 2 & 38.92 & Hydrophis curtus & Q8UW30 & basic phospholipase $A_{2} 73$ & 0.91 \\
\hline & 2 & 31.08 & Denisonia devisi & R4G2S8 & PLA-2-Den-2 & 1.82 \\
\hline 7 & 13 & 242.58 & Hydrophis curtus & CL2848.Contig2_HCM & Extracellular matrix protein 1 & 0.16 \\
\hline 8 & 8 & 143.01 & Hydrophis curtus & CL2323.Contig2_HCM & Lysozyme C, milk isozyme-like & 0.77 \\
\hline \multirow[t]{3}{*}{9} & 8 & 148.33 & Hydrophis curtus & Q8UW11 & Cysteine-rich venom protein 2 & 3.28 \\
\hline & 6 & 111.6 & Enhydrina schistosa & CL131.Contig1_ESM & Cysteine-rich secretory protein & 3.42 \\
\hline & 3 & 51.38 & Hydrophis curtus & Q8UW25 & Cysteine-rich venom protein 1 & 1.49 \\
\hline
\end{tabular}


Table 1. Cont.

\begin{tabular}{|c|c|c|c|c|c|c|}
\hline Fraction & Distinct Peptides & MS/MS Search Score & $\begin{array}{c}\text { Species } \\
\text { (as Per Annotation in Database) }\end{array}$ & Database Accession $^{a}$ & $\begin{array}{c}\text { Protein Name } \\
\text { (as Per Annotation in Database) }\end{array}$ & Relative Abundance (\%) \\
\hline \multirow[t]{21}{*}{10} & 23 & 394.95 & Ophiophagus hannah & P81383 & L-amino-acid oxidase & 0.18 \\
\hline & 20 & 351.67 & Hydrophis curtus & Unigene7803_HCM & Transferrin & 0.15 \\
\hline & 12 & 197.37 & Ophiophagus hannah & $\mathrm{I} 2 \mathrm{C} 090$ & Ophiophagus venom factor & 0.06 \\
\hline & 8 & 139.98 & Ophiophagus hannah & CL304.Contig1_OHM & OVF precursor protein & 0.05 \\
\hline & 9 & 144.94 & Hydrophis curtus & CL4561.Contig1_HCM & Glutathione peroxidase 3 & 0.07 \\
\hline & 8 & 138.68 & Enhydrina schistosa & CL1665.Contig1_ESM & Sulfhydryl oxidase 1-like & 0.07 \\
\hline & 7 & 124.2 & Hydrophis curtus & Q8UW11 & Cysteine-rich venom protein 2 & 0.81 \\
\hline & 7 & 122.36 & Hydrophis curtus & CL4690.Contig9_HCM & Phospholipase A2 inhibitor & 0.20 \\
\hline & 6 & 89.52 & Ovophis okinavensis & U3TDL2 & glutaminyl_cyclase & 0.02 \\
\hline & 4 & 69.73 & Hydrophis curtus & Unigene19328_HCM & Phospholipase $\mathrm{A} 2$ inhibitor beta & 0.25 \\
\hline & 4 & 54.96 & Hydrophis curtus & CL2048.Contig1_HCM & Multiple inositol polyphosphate phosphatase 1 & 0.05 \\
\hline & 3 & 46.73 & Hydrophis curtus & CL1278.Contig2_HCM & Phospholipase B & 0.02 \\
\hline & 3 & 45.91 & Enhydrina schistosa & CL560.Contig2_ESM & Carinatease-1 & 0.09 \\
\hline & 2 & 37.92 & Hydrophis curtus & CL4690.Contig1_HCM & Scutatease-1 & 0.22 \\
\hline & 2 & 35.54 & Hydrophis curtus & Unigene390_HCM & Zinc metalloproteinase-disintegrin-like NaMP & 0.05 \\
\hline & 2 & 36.44 & Enhydrina schistosa & CL79.Contig2_ESM & ADP-ribosyl cyclase 1 & 0.01 \\
\hline & 2 & 34.29 & Enhydrina schistosa & CL98.Contig1_ESM & Lysosomal Pro-X carboxypeptidase-like & 0.04 \\
\hline & 2 & 32.92 & Hydrophis curtus & Unigene20804_HCM & Phosphodiesterase & 0.04 \\
\hline & 2 & 32.47 & Hydrophis curtus & CL1263.Contig2_HCM & Golgi apparatus protein 1 & 0.02 \\
\hline & 2 & 30.78 & Hydrophis curtus & Unigene23143_HCM & $\mathrm{N}$-acetylglucosamine-6-sulfatase & 0.02 \\
\hline & 2 & 29.28 & Ophiophagus hannah & CL2083.Contig1_OHM & OVF precursor protein & 0.03 \\
\hline
\end{tabular}

a Protein codes with suffix " HCM", “_ESM", “ OHM", “ CIM", “ BCSL" and “_NNSL” were derived from the in-house database containing RNAseq specific for the following: HCM:

Malaysian Hydrophis curtus; ESM: Malaysian Hydrophis schistosus; OHM: Malaysian Ophiophagus hannah; CIM: Malaysian Calliophis intestinalis; BCSL: Sri Lankan Bungarus caeruleus; NNSL:

Sri Lankan Naja naja. ${ }^{\mathrm{b}}$ Protein abundance was interpreted as the percentage of total venom proteins. Cysteine residues determined in MS/MS analysis are carbamidomethylated. Protein

identifications were validated with the following filters: protein score $>11$, peptides score $>6$ and scored peak intensity (SPI) $>60 \%$. The relative abundance of an individual protein was estimated based on its relative spectral intensity within an HPLC fraction and the chromatographic peak area under the curve (AUC). 
Table 2. Overview of Malaysian (Penang) Hydrophis curtus venom proteome by protein families and subtypes with relative abundances (\%).

\begin{tabular}{|c|c|c|c|}
\hline Protein Family/Protein Subtype & Fraction & Accession Code ${ }^{a}$ & Relative Abundance (\%) ${ }^{b}$ \\
\hline Phospholipases $\mathrm{A}_{2}$ & & & 62.00 \\
\hline Acidic PLA 2 & & & 48.26 \\
\hline Acidic phospholipase $A_{2} 57$ & $4,5,6$ & Q8UW31 & 28.68 \\
\hline PLA-2-Den-2 & 6 & R4G2S8 & 1.82 \\
\hline Acidic phospholipase $\mathrm{A}_{2} 57$ & 5,6 & Unigene17389_BCSL & 15.31 \\
\hline Acidic phospholipase $\mathrm{A}_{2} 57$ & 4,5 & Unigene22561_ESM & 2.15 \\
\hline Acidic phospholipase $\mathrm{A}_{2} 57$ & 4,5 & CL2932.Contig3_CIM & 0.31 \\
\hline Basic PLA 2 & & & 13.74 \\
\hline Basic phospholipase $\mathrm{A}_{2}$ & $4,5,6$ & P00610 & 4.15 \\
\hline Basic phospholipase $\mathrm{A}_{2}$ & 5,6 & Q8UW08 & 2.66 \\
\hline Basic phospholipase $A_{2} 73$ & $4,5,6$ & Q8UW30 & 4.01 \\
\hline Basic phospholipase $A_{2}$ & 5 & CL339.Contig1_NNSL & 2.85 \\
\hline Basic phospholipase $A_{2} 73$ & 4 & CL4079.Contiḡ__HCM & 0.07 \\
\hline Three-finger toxins & & & 26.33 \\
\hline Short Neurotoxin & & & 22.89 \\
\hline Short neurotoxin 1 & 1 & P68416 & 22.89 \\
\hline Long Neurotoxin & & & 3.44 \\
\hline Long neurotoxin 2 & 2,3 & A3FM53 & 1.81 \\
\hline Long neurotoxin $\mathrm{OH}-56$ & 3 & Q53B57 & 0.21 \\
\hline Long neurotoxin $\mathrm{OH}-55$ & 3 & Q53B58 & 0.33 \\
\hline Long neurotoxin 1 & 3 & Q8UW29 & 1.10 \\
\hline Cysteine-rich secretory protein & & & 9.00 \\
\hline Cysteine-rich venom protein 2 & 9,10 & Q8UW11 & 4.09 \\
\hline Cysteine-rich venom protein 1 & 9 & Q8UW25 & 1.49 \\
\hline Cysteine-rich secretory protein & 9 & CL131.Contig1_ESM & 3.42 \\
\hline Phospholipase $\mathrm{A}_{2}$ inhibitors & & & 0.45 \\
\hline Phospholipase $\mathrm{A}_{2}$ inhibitor beta & 10 & Unigene19328_HCM & 0.25 \\
\hline Phospholipase $\mathrm{A}_{2}$ inhibitor & 10 & CL4690.Contig9_HCM & 0.20 \\
\hline Snake venom metalloproteinases & & & 0.36 \\
\hline Zinc metalloproteinase-disintegrin-like NaMP & 10 & Unigene390_HCM & 0.05 \\
\hline Scutatease-1 & 10 & CL4690.Contig1_HCM & 0.22 \\
\hline Carinatease-1 & 10 & CL560.Contig2_ESM & 0.09 \\
\hline L-amino acid oxidase & & & 0.18 \\
\hline L-amino-acid oxidase & 10 & P81383 & 0.18 \\
\hline Ophiophagus venom factor & & & 0.14 \\
\hline Ophiophagus venom factor & 10 & I2C090 & 0.06 \\
\hline OVF precursor protein & 10 & CL304.Contig1_OHM & 0.05 \\
\hline OVF precursor protein & 10 & CL2083.Contig1_OHM & 0.03 \\
\hline Waprin & & & 0.11 \\
\hline Waprin-Rha1 & 4 & Unigene14087_HCM & 0.11 \\
\hline Phosphodiesterase & & & 0.04 \\
\hline Phosphodiesterase & 10 & Unigene20804_HCM & 0.04 \\
\hline Phospholipase B & & & 0.02 \\
\hline Phospholipase B & 10 & CL1278.Contig2_HCM & 0.02 \\
\hline Non-toxin & & & 1.38 \\
\hline Extracellular matrix protein 1 & 7 & CL2848.Contig2_HCM & 0.16 \\
\hline Lysozyme C, milk isozyme-like & 8 & CL2323.Contig2_HCM & 0.77 \\
\hline Transferrin & 10 & Unigene7803_HCM & 0.15 \\
\hline Glutathione peroxidase 3 & 10 & CL4561.Contig1_HCM & 0.07 \\
\hline Sulfhydryl oxidase 1-like & 10 & CL1665.Contig1_ESM & 0.07 \\
\hline Glutaminyl_cyclase & 10 & U3TDL2 & 0.02 \\
\hline Multiple inositol polyphosphate phosphatase 1 & 10 & CL2048.Contig1_HCM & 0.05 \\
\hline ADP-ribosyl cyclase 1 & 10 & CL79.Contig2_ESM & 0.01 \\
\hline Lysosomal Pro-X carboxypeptidase-like & 10 & CL98.Contig1_ESM & 0.04 \\
\hline Golgi apparatus protein 1 & 10 & CL1263.Contig2_HCM & 0.02 \\
\hline $\mathrm{N}$-acetylglucosamine-6-sulfatase & 10 & Unigene23143_HCM & 0.02 \\
\hline
\end{tabular}

a Protein codes with suffix “_HCM", “_ESM", "_OHM", "_CIM", "_BCSL" and "_NNSL" were derived from the in-house database containing RNAseq specific for the following: HCM: Malaysian Hydrophis curtus; ESM: Malaysian Hydrophis schistosus; OHM: Malaysian Ophiophagus hannah; CIM: Malaysian Calliophis intestinalis; BCSL: Sri Lankan Bungarus caeruleus; NNSL: Sri Lankan Naja naja. ${ }^{\mathrm{b}}$ Protein abundance was interpreted as the percentage of total venom proteins. 
Table 3. Venom proteomic profiles of sea elapids (sea snakes and sea krait). Values indicate the relative abundances of the proteins (by total venom protein).

\begin{tabular}{|c|c|c|c|c|c|c|c|c|}
\hline Species & $\begin{array}{c}\text { H. curtus (Penang) } \\
n=10 \text { Adults } \\
\text { Dry Weight Per Milking: } \\
\sim 1-8 \mathrm{mg}\end{array}$ & $\begin{array}{c}\text { H. curtus } \\
\text { (January, Weipa) } \\
n=11 \text { Adults }\end{array}$ & $\begin{array}{l}\text { H. curtus (June, } \\
\text { Weipa) } \\
n=10 \text { Subadults }\end{array}$ & $\begin{array}{l}\text { H. schistosus } \\
\text { (Penang) } \\
n=10 \text { Adults }\end{array}$ & $\begin{array}{c}\text { L. colubrina } \text { (Bali) } \\
\quad n=\text { Several }\end{array}$ & $\begin{array}{l}\text { Aipysurus laevus } \\
\text { (Broome) } \\
n=4\end{array}$ & $\begin{array}{l}\text { H. platura (Costa } \\
\text { Rica) } \\
n=84\end{array}$ & $\begin{array}{l}\begin{array}{l}\text { H. cyanocinctus } \\
\text { (Hara) } \\
n=\text { Several }\end{array}\end{array}$ \\
\hline $\begin{array}{c}\text { i.v. } \text { LD }_{50} \\
(\mu \mathrm{g} / \mathrm{g} \text { mouse })\end{array}$ & $0.20(0.18-0.24)$ & NA & NA & $0.07(0.05-0.09)$ & $0.10(0.08-0.12)$ & $0.15(0.08-0.25)$ & $\begin{array}{l}0.23 \\
\text { (note: } 0.13 \text { by i.p. } \\
\text { route) }\end{array}$ & 0.132 \\
\hline Reference & Current study & \multicolumn{2}{|c|}{ Neale et al. (2017) [20] } & $\begin{array}{c}\text { Tan et al. (2015b) } \\
\text { [12] }\end{array}$ & $\begin{array}{c}\text { Tan et al. (2017) } \\
\text { [19] }\end{array}$ & $\begin{array}{l}\text { Laustsen et al. } \\
\text { (2015) [18] }\end{array}$ & $\begin{array}{l}\text { Lomonte et al. } \\
\text { (2014) [17] }\end{array}$ & $\begin{array}{c}\text { Calvete et al. (2012) } \\
\text { [16] }\end{array}$ \\
\hline Methods & $\begin{array}{c}\text { C18 rpHPLC, } \\
\text { in-solution tryptic digestion, } \\
\text { LCMS/MS }\end{array}$ & $\begin{array}{c}\text { C4 rpHPLC, } \\
\text { in-solution tryptic } \\
\text { digestion, } \\
\text { LCMS/MS }\end{array}$ & $\begin{array}{c}\text { C4 rpHPLC, } \\
\text { in-solution tryptic } \\
\text { digestion, } \\
\text { LCMS/MS }\end{array}$ & $\begin{array}{c}\text { C18 rpHPLC, } \\
\text { in-gel tryptic } \\
\text { digestion, MALDI } \\
\text { TOF/TOF }\end{array}$ & $\begin{array}{l}\text { C18 rpHPLC, } \\
\text { in-solution tryptic } \\
\text { digestion, } \\
\text { LCMS/MS }\end{array}$ & $\begin{array}{c}\text { C18 rpHPLC, } \\
\text { in-gel tryptic } \\
\text { digestion, MALDI } \\
\text { TOF/TOF }\end{array}$ & $\begin{array}{l}\text { C18 rpHPLC, } \\
\text { in-gel tryptic } \\
\text { digestion, } \\
\text { LCMS/MS }\end{array}$ & $\begin{array}{l}\text { C18 rpHPLC, } \\
\text { N-terminal } \\
\text { sequencing, in-gel } \\
\text { tryptic digestion, } \\
\text { CID-MS/MS }\end{array}$ \\
\hline 3FTX & 26.33 & 30.44 & 40.43 & 70.5 & 66.14 & 25.3 & $\sim 49.9$ & 81.1 \\
\hline SNTX & 22.89 & 8.33 & 20.76 & 55.8 & 16.94 & 25.3 & $\sim 36$ & 51.7 \\
\hline LNTX & 3.44 & 22.11 & 19.67 & 14.7 & 48.9 & - & $\sim 14$ & 29.4 \\
\hline CTX & - & - & - & - & 0.3 & & - & - \\
\hline $\mathrm{PLA}_{2}$ & 62.00 & 66.7 & 54.50 & 27.5 & 33.3 & 71.2 & 32.9 & 18.9 \\
\hline Acidic & 48.26 & 57.93 & 41.21 & 6.1 & 0.04 & 46.4 & $N A$ & $N A$ \\
\hline Basic & 13.74 & 8.76 & 13.28 & 21.4 & 33.26 & 24.8 & $N A$ & $N A$ \\
\hline Neutral & - & 0.01 & 0.007 & - & - & - & $N A$ & NA \\
\hline CRISP & 9.00 & 2.53 & 4.95 & 1.3 & 0.05 & 2.5 & 9.1 & - \\
\hline LAAO & 0.18 & - & - & 0.2 & - & - & - & - \\
\hline SVMP & 0.36 & 0.004 & 0.01 & 0.5 & - & - & $\sim 0.9$ & - \\
\hline NUC & - & - & - & - & - & - & $\sim 0.8$ & - \\
\hline CTL & - & 0.09 & 0.003 & - & - & - & - & - \\
\hline PDE & 0.04 & - & - & - & - & - & - & - \\
\hline PLB & 0.02 & - & - & - & - & - & - & - \\
\hline PLA $_{2}$ inhibitor & 0.45 & 0.01 & - & - & - & - & - & - \\
\hline OVF & 0.14 & - & - & - & - & - & - & - \\
\hline Waprin & 0.11 & - & - & - & - & - & - & - \\
\hline $\begin{array}{l}\text { Non-toxins/cellular } \\
\text { proteins }\end{array}$ & 1.38 & 0.231 & 0.12 & - & - & 0.2 & 5.0 & - \\
\hline Unknown & - & - & - & - & 0.57 & 0.8 & 1.4 & - \\
\hline
\end{tabular}

Abbreviations: $\mathrm{LD}_{50}$ : median lethal dose; i.v.: intravenous; i.p.: intraperitoneal; rpHPLC: reverse-phase high performance liquid chromatography; LCMS/MS: Liquid chromatography-tandem mass spectrometry; MALDI TOF/TOF: Matrix assisted laser desorption/ionization-time of flight tandem mass spectrometry; CID-MS/MS: Collision-induced dissociation-tandem mass spectrometry; 3FTX: three-finger toxin; SNTX: Short alpha-neurotoxin; LNTX: Long alpha-neurotoxin; CTX: Cytotoxin; PLA 2 : Phospholipase $\mathrm{A}_{2}$; CRISP: Cysteine-rich secretory protein; LAAO: L-amino acid oxidase; SVMP: Snake venom metalloproteinase; NUC: Nucleotidase; CTL: C-type lectin; PDE: Phosphodiesterase; PLB: Phospholipase B; OVF: Ophiophagus venom factor. NA: Not available. 


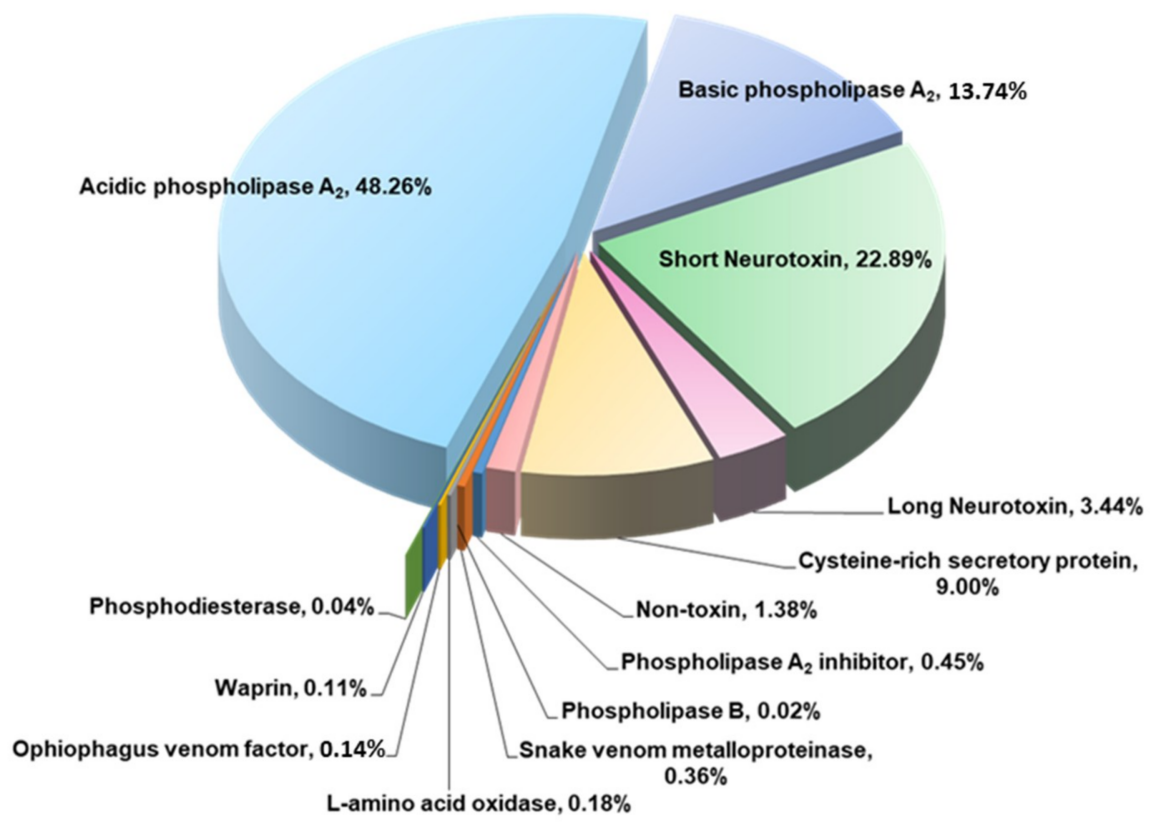

Figure 2. Venom proteome of the spine-bellied sea snake, Hydrophis curtus from Penang Island, Malaysia. Percentages indicate relative protein abundance by total venom proteins.

\subsection{Immunoreactivity Profiling of H. curtus Venom Proteins}

Figure 3 shows the immunoreactivity of SSAV toward the different venom fractions (10 ng protein) of H. curtus, the holovenoms of H. curtus, Notechis scutatus, H. schistosus and C. rhodostoma. The binding activity of SSAV (reflected by the absorbance on ELISA) toward H. curtus and N. scutatus venoms were high $(\mathrm{Abs}>1.0)$ but marginally lower toward $H$. schistosus venom. The negative control, C. rhodotoma venom, exhibited weak binding by SSAV (Abs $~ 0.1$ ). Among the protein fractions, Fraction 6 (containing the major PLA $_{2}$ proteins) immunoreacted most strongly with SSAV (Abs $\sim 1.0$ ). Fractions 1 (SNTX), 4 and 5 (PLA2) showed moderate immunoreactivity (Abs: 0.6-0.7), whereas Fractions 2, 3 (LNTX) and 7 (non-toxin components) were relatively weak in their immunoreactivity (Abs 0.3). SSAV binding activity toward proteins in Fractions 8 (non-toxin), 9 (CRISP) and 10 (enzymes, inhibitors and non-toxin components) were considerably low, with average absorbance values of $<0.2$.

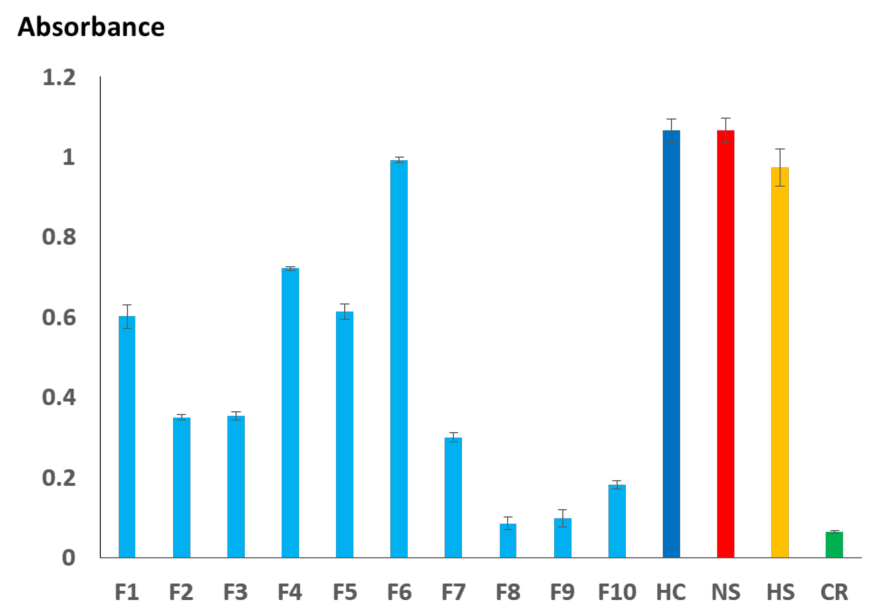

Figure 3. Immunoprofiling of $H$. curtus venom and protein fractions by the heterologous Sea Snake Antivenom. F1-F10: Reverse-phase HPLC of H. curtus venom; HC: H. curtus venom; NS: Notechis scutatus venom; HS: Hydrophis schistosus venom; CR: Calloselasma rhodostoma venom. 


\subsection{Toxicity of H. curtus Venom and Principal Toxins}

The Malaysian H. curtus venom was lethal in mice with an intravenous $\mathrm{LD}_{50}$ of $0.20(0.18-0.24)$ $\mu \mathrm{g} / \mathrm{g}$. The SNTX (F1) and LNTX (F3) were both lethal, and the SNTX appeared to be more toxic $\left(\mathrm{LD}_{50}=0.10 \mu \mathrm{g} / \mathrm{g}\right)$ than LNTX $\left(\mathrm{LD}_{50}=0.24 \mu \mathrm{g} / \mathrm{g}\right)$. Screening of toxicity for all other fractions including the major fractions F4 and F6 which contained primarily PLA 2 , as well as F9 which contained CRISP, showed that these proteins were non-lethal in mice at a dose $>1 \mu \mathrm{g} / \mathrm{g}$.

\subsection{Cross-Neutralization of H. curtus Venom and Toxins by SSAV}

In neutralization assay, SSAV cross-neutralized the whole venom effectively at a potency of $2.03 \mathrm{mg} / \mathrm{mL}$ (amount of venom completely neutralized by one milliliter of antivenom), equivalent to the normalized potency of $9.35 \mathrm{mg} / \mathrm{g}$ (amount of venom or toxin neutralized by one gram of antivenom protein). SSAV cross-neutralized the principal toxins i.e., SNTX and LNTX to different extents: the normalized potency values against SNTX and LNTX were $1.57 \mathrm{mg} / \mathrm{g}$ and $3.50 \mathrm{mg} / \mathrm{g}$, respectively. All challenge doses (venom and toxins) were standardized at $5 \mathrm{LD}_{50}$. The neutralization parameters i.e., median effective doses $\left(E D_{50}\right)$, median effective ratio $\left(E_{50}\right)$, potency $(P)$ and normalized potency $(n-P)$ are shown in Table 4.

Table 4. Efficacy and potency of Seqirus Sea Snake Antivenom (SSAV) in cross-neutralizing the lethal effect of Hydrophis curtus venom and toxin fractions.

\begin{tabular}{|c|c|c|c|c|c|c|c|}
\hline $\begin{array}{l}\text { Venom/ } \\
\text { Fraction }\end{array}$ & $\begin{array}{c}\text { Challenge } \\
\text { Dose }\end{array}$ & $\begin{array}{l}\text { i.v. } L_{50} \\
(\mu g / g)^{a}\end{array}$ & $\mathrm{ED}_{50}(\mu \mathrm{L})^{b}$ & $\begin{array}{c}\mathrm{ER}_{50} \\
(\mathrm{mg} / \mathrm{mL})^{\mathrm{c}}\end{array}$ & $\begin{array}{l}\text { Potency, P } \\
(\mathrm{mg} / \mathrm{mL}){ }^{\mathrm{d}}\end{array}$ & $\begin{array}{l}\text { SSAV Protein } \\
\text { Concentration } \\
\quad(\mathrm{mg} / \mathrm{mL})\end{array}$ & $\begin{array}{c}\text { Normalized } P, \\
n-P(m g / g)\end{array}$ \\
\hline Venom & 5 & $\begin{array}{c}0.20 \\
(0.18-0.24)\end{array}$ & $\begin{array}{c}9.87 \\
(7.98-12.21)\end{array}$ & $\begin{array}{c}2.53 \\
(2.28-3.04)\end{array}$ & $\begin{array}{c}2.03 \\
(1.83-2.43)\end{array}$ & $217.2 \pm 3.0$ & 9.35 \\
\hline F1_SNTx & 5 & $\begin{array}{c}0.10 \\
(0.08-0.12)\end{array}$ & $\begin{array}{c}25.82 \\
(22.38-29.79)\end{array}$ & $\begin{array}{c}0.41 \\
(0.34-0.51)\end{array}$ & $\begin{array}{c}0.34 \\
(0.27-0.41)\end{array}$ & $217.2 \pm 3.0$ & 1.57 \\
\hline F3_LNTx & 5 & $\begin{array}{c}0.24 \\
(0.21-0.28)\end{array}$ & $\begin{array}{c}27.90 \\
(25.36-30.70)\end{array}$ & $\begin{array}{c}0.95 \\
(0.83-1.10)\end{array}$ & $\begin{array}{c}0.76 \\
(0.66-0.88)\end{array}$ & $217.2 \pm 3.0$ & 3.50 \\
\hline F5 & - & $>1$ & - & - & - & - & - \\
\hline F6 & - & $>1$ & - & - & - & - & - \\
\hline F9 & - & $>1$ & - & - & - & - & - \\
\hline
\end{tabular}

$\mathrm{LD}_{50}$ : Median lethal dose; $\mathrm{ED}_{50}$ : Median effective dose; $\mathrm{ER}_{50}$ : Median effective ratio; ${ }^{\mathrm{a}}$ Median lethal dose was defined as the dose of venom $(\mu \mathrm{g} / \mathrm{mL})$ at which $50 \%$ of mice died. ${ }^{b}$ Median effective dose was defined as the dose of antivenom $(\mu \mathrm{L})$ at which $50 \%$ of mice survived. ${ }^{c}$ Median effective ratio was defined as the ratio of venom $(\mathrm{mg})$ to the volume does of antivenom $(\mathrm{mL})$ at which $50 \%$ of mice survived. $\mathrm{d}$ Potency, $\mathrm{P}$, the neutralization potency of antivenom $(\mathrm{mg} / \mathrm{mL})$ was defined as the amount of venom $(\mathrm{mg})$ that was completely neutralized by one $\mathrm{mL}$ of antivenom. ${ }^{\mathrm{e}}$ Normalized $\mathrm{P}, \mathrm{n}-\mathrm{P}$ was defined as the neutralization potency of the antivenom in mg venom/g antivenom.

\section{Discussion}

C18 reverse-phase HPCL and gel electrophoresis revealed a common trend of venom profiles between Hydrophis curtus and related venomous marine snakes. This is consistent with the perceived "streamlining of venom" as an adaptive feature for predation in the aquatic environment, where fish is the main targeted prey. The venom chromatograms of $H$. curtus (current study) and its monophyletic cousin H. schistosus [12] both showed well resolved, less complex protein peaks in the following regions (based on an optimized venom-decomplexing protocol) [27]: 30-35 min, 60-75 min and 90-120 min, which corresponded to the elution of SNTX, LNTX and PLA 2 , respectively. The similar pattern of protein elution was reported for virtually all sea elapid venom profiles (using reverse-phase column), and the three toxin groups typically constitute the bulk of the venom proteins at $>95 \%$ (by weight), although the individual protein subtypes and their individual expression could vary substantially at the inter- and intra-specific levels. Compared to H. schistosus, which has a more specialized diet (feeding mainly on tachysurus catfish), H. curtus is known to be generalistic, and a greater complexity of venom proteins is probably needed to subdue and digest different types of prey. This might be 
reflected in the more diverse protein types/subtypes and variable protein expression in $H$. curtus venom compared to $H$. schistosus profile at the subproteomic level.

On the whole, the venom proteomes of the congeneric Hydrophis sp. (H. curtus, H. schistosus, H. platurus, $H$ cyanocinctus) and the paraphyletic A. laevus showed that 3FTX were invariably alpha-neurotoxins of short- and/or long-chain proteoforms (SNTX and LNTX). Alpha-neurotoxins are post-synaptic antagonists of post-junctional nicotinic acetylcholine receptors (nAChR); blockade of neurotransmission caused by these NTX can lead to neuromuscular paralysis, respiratory failure and death $[28,29]$. SNTX are generally more reversible than LNTX in receptor binding (inactivation of nAChR), but they are less well neutralized in vivo by commercial antivenoms, as shown in several toxin-specific neutralization studies $[25,30,31]$. The abundance of SNTX appears to be a limiting factor of antivenom efficacy (in neutralizing the venom toxicity), and this has an implication on antivenom production, i.e., that elapid antivenom efficacy should be improved by optimizing the formulation of toxin immunogen, taking into account the poorly neutralized neurotoxins. The Malaysian H. curtus venom (the object of the current study) has more SNTX than LTNX (SNTX:LNTX ratio of 10:1); this SNTX-predominating trend in the subproteome is observed in the congeneric H. schistosus (SNTX:LNTX $\sim 4: 1$ ), H. platura (SNTX:LNTX 2:1), H. cyanocinctus (SNTX:LNTX 2:1), and the paraphyletic A. laevus which venom contained only SNTX [12,16-18]. On the other hand, the semi-marine L. colubrina (Bali) has more LNTX than SNTX (LNTX:SNTX 3:1) in its venom [19], probably a feature related to its strict diet of eels. This could be an indicator for the evolutionary status of L. colubrina being basal to all other lineages, including the Australasian terrestrial elapids and the fully marine hydrophids nested within [21]. The three-finger neurotoxin profile is typically much more diverse in the terrestrial counterparts e.g., cobras [32], kraits [33] and coral snakes [34,35] but highly streamlined to SNTX in the hydrophids $[12,17]$.

In the recently published venom proteome of H. curtus sourced from Weipa (Northern Australia), the alpha-NTX profile varied between two catches (January batch with body length $>600 \mathrm{~mm}$ vs. June batch with body length $<400 \mathrm{~mm}$ ) [20]. In the January catch, that was categorized as adults $(n=10)$, the alpha-neurotoxins were predominantly LNTX (LNTX:SNTX $\sim 3: 1$ ), whereas LNTX and SNTX were equally abundant in the June catch (subadults, $n=10$ ) (LNTX:SNTX $\sim 1: 1$ ). The profiles reported previously were varied from the current study in terms of the neurotoxin diversity and the ratio of SNTX to LNTX. The reverse-phase HPLC and the LCMS/MS data of H. curtus venoms also varied between the previous and the current studies. Notably, the first chromatographic peak (corresponding to SNTX elution) was remarkably much higher (with a larger AUC) followed by significantly lower peaks (10-fold smaller) of LNTX in the Malaysian sample, whereas in the Australian specimen, the main fractions containing LNTX (Fractions 2 and 3) showed comparable peak heights with its SNTX-containing Fraction 1 [20]. It was also noted that the neurotoxins (in particular LNTX) in the Australian H. curtus venom samples eluted across all chromatographic fractions (Fractions 1-11) in the previous study; this makes comparison on the elution pattern and protein abundance of NTX between different chromatograms rather challenging. The inconsistent resolution of NTX could be due to the different type of column materials used: the C18 column used in the present and most other venomic studies has a longer hydrocarbon chain bonded to the silica (as octadecylsilane); this packing material is inherently more hydrophobic and has a longer retention time for proteins compared to the C4 column. On reducing SDS-PAGE, the profiling of protein fractions (by molecular weights) from C18 reverse-phase HPLC (current study) was highly consistent with the protein identification by LCMS/MS for all fractions. Comparison of SDS-PAGE profiles for the venoms and corresponding HPLC fractions between the Malaysian and the Australian H. curtus was precluded, as the SDS-PAGE of Australian specimen was not available. Nonetheless, the proteomes reported thus far illustrate the remarkable variability of the highly evolved neurotoxins between the two geographical $H$. curtus populations.

Despite the differences in their 3FTX (neurotoxin) profile, PLA $_{2}$ is consistently the most dominant proteins in the venoms of the Malaysian ( $>60 \%$, current study) and the Australian H. curtus (55-67\%) [20]. This phenomenon was also seen in A. laevus venom, in which $\mathrm{PLA}_{2}$ constituted $>70 \%$ 
of the total venom proteins. The PLA 2 dominance in these species is "balanced" with a lower 3FTX abundance, as shown in the Malaysian H. curtus ( $26 \%$, current study) and the Australian A. laevus $(\sim 25 \%)$ [18], although the Australian H. curtus venom contained a slightly higher abundance of 3FTX (30-40\%) [20]. This venomic phenotype contrasts with the venom proteomes reported previously for the other core Hydrophis sea snakes (H. cyanocinctus, H. schistosus and H. platurus) $[12,16,17]$, as well as the taxonomically-divergent L. colubrina [19], in which three-finger alpha-neurotoxins are dominant (50-81\%). The unique subproteomic variability of $H$. curtus venom delineates a potential NTX-PLA 2 dichotomy among the Hydrophis sea snakes, which should be further verified when more sea snake venom proteomes become available. The variable expression of neurotoxins and PLA 2 presumably correlates with the venom neurotoxic and myotoxic activities, supporting the relationship between snake venom compositions and feeding adaptations in different niches. Clinically, the relatively lower alpha-neurotoxins abundance and higher PLA $_{2}$ content imply that the pathophysiology of H. curtus envenoming possibly varies from other sea snake species that demonstrate a neurotoxin-predominating venom composition. Considering their high abundances, the $\mathrm{PLA}_{2}$ likely play a crucial role in the toxic activity of $H$. curtus venom. However, $\mathrm{PLA}_{2}$ is pharmacologically diverse [36], and the high number of $\mathrm{PLA}_{2}$ subtypes within the venom indicates that the PLA 2 functionality is complex. In H. curtus, the predominating $\mathrm{PLA}_{2}$ are of acidic subtypes which were probably not as effective as sea snake basic $\mathrm{PLA}_{2}$ at penetrating the membrane phospholipids to cause cytotoxicity and myotoxicity [11,37]. The high acidic:basic PLA 2 proportion in the Malaysian H. curtus venom proteome (4:1) is in line with proportions reported for the Australian H. curtus (3:1, 7:1) [20] and A. laevus (2:1) [18], but opposite to the Malaysian H. schistosus (1:4) [12] and the Balinese L. colubrina, whose venom virtually composed of basic PLA 2 (acidic PLA 2 was only present in a trace amount) [19]. Although it is generally well accepted that the basic $\mathrm{PLA}_{2}$ proteins contribute more substantially to venom lethality than acidic $\mathrm{PLA}_{2}$, the biological activities of the different $\mathrm{PLA}_{2}$ proteoforms (acidic or basic) can vary between snake species. The PLA 2 activity may or may not be clinically important, as shown in several acidic or even basic PLA 2 that are non-lethal from elapid venoms $[19,25,31]$. In studies of sea snake venom, the equivocal toxicity of $\mathrm{PLA}_{2}$ could be further elucidated with isolated toxin study (discussed below) to correlate with the clinical or epidemiological findings. In most sea snake envenoming, however, $H$. curtus bite has not been well identified and documented.

The diversity and the dominating proportion of $H$. curtus venom proteins in this study also differed from a previous work that studied cDNA libraries cloned from venom-gland mRNA of $H$. curtus (Lapemis curtus) sampled from Weipa, Australia [21]. The venom gene transcription appeared to bias toward 3FTX (43.4\%) compared to PLA $2(9.8 \%)$, contrasting with the established venom proteome of this species (regardless of Weipa or Penang origin) in which $\mathrm{PLA}_{2}$ dominated $\left(\mathrm{PLA}_{2}>3 \mathrm{FTX}\right.$, by total venom proteins). The incongruence between venom-gland transcriptome and venom proteome of snake has been well documented in several other species, such as the monocled cobra [38] and king cobra [39], indicating that there is significant post-transcription regulation and/or post-translational modification in the synthesis of snake venom proteins.

The cysteine-rich secretory protein (CRiSP) family contributes to a relatively high protein abundance in the Malaysian H. curtus venom. CRiSP was reported in the proteomes of virtually all sea snake venoms except for $H$. cyanocinctus [16], where its absence could be due to a lower detection sensitivity of mass spectrometry and instrument used previously. The abundance of CRiSP in the Malaysian H. curtus venom is consistent with that reported for the adult H. curtus (Weipa) and A. laevus (Broome). CRiSP exhibits diverse biological activities such as the inhibition of smooth muscle contraction, blockade of cyclic nucleotide-gated ion channel, and hypothermia in animals [40,41]. Clinically, the pathophysiological role of CRiSP in snakebite in humans is still unclear, and is worthy of further investigation. Characterization of the novel CRiSP from the Malaysian H. curtus venom is highly feasible in view of the abundance and purity of the protein (judged by its homogeneity on SDS-PAGE) eluted using the current HPLC protocol. 
Other proteins present in the venom proteome were minor components (on average $<1 \%$ each). The variety of these minor proteins, interestingly, is greater than in other sea elapids reported so far. The sea snake venom L-amino acid oxidase (LAAO) enzyme was detected proteomically for the second time in sea elapids, after the first report in the H. schistosus venom proteome [12]. This finding implies that LAAO could be a trace enzyme that exists in at least two species of the core Hydrophis genus, enriching our knowledgebase and demonstrating that sea snake venoms are not totally devoid of LAAO [42].

The detection of snake venom metalloproteinase (SVMP) in the Malaysian H. curtus venom is consistent with what had been observed in the venom proteomes of the Australian H. curtus and the Malaysian H. schistosus [12,20]. The contents of SVMP in the Malaysian H. curtus and H. schistosus were, however, markedly higher than the Australian H. curtus. As these were the four sea snake venom samples shown to contain SVMP thus far, it is uncertain whether the distribution of SVMP in sea snakes is geographically related. Besides, the Malaysian H. curtus venom contains phosphodiesterase, phospholipase B, Ophiophagus venom factor and waprin and this is the first report of the presence of these proteins in the venom proteomes of sea snakes, although weak phosphoesterase enzymatic activity had been reported previously from Lapemis hardwickii (H. curtus) venom [43]. The roles of these minor proteins in the venom remain to be further investigated.

In the in vivo toxicity test, $H$. curtus venom showed an approximately 2 -fold higher $L_{50}$ compared to H. schistosus ( $\mathrm{LD}_{50}=0.07 \mu \mathrm{g} / \mathrm{g}$ ) and L. colubrina $(0.10 \mu \mathrm{g} / \mathrm{g})$. In line with the current proteomic findings, the lower lethality of $H$. curtus venom is driven by its lower 3FTX content (alpha-neurotoxins, 26.33\%) in contrast to the more lethal H. schistosus venom (alpha-neurotoxins, 70.5\%; myotoxic PLA $2, \sim 20 \%$ ) and L. colubrina (alpha-neurotoxins, 66.14\%) [12,19]. Considering the relative abundances of $H$. curtus SNTX ( 22.89\%) and LNTX ( 3.44\%), in one unit of $\mathrm{LD}_{50}$ of the whole venom $(0.2 \mu \mathrm{g} / \mathrm{g}$ mouse), there are approximately $0.046 \mu \mathrm{g}$ SNTX and $0.007 \mu \mathrm{g}$ LNTX, which represent $46 \%$ and $2.9 \%$ of the $\mathrm{LD}_{50}$ of the neurotoxin subtypes, respectively. This indicates that SNTX and LNTX may work in synergism, contributing to the whole venom lethality, and antivenom treatment should seek to address effective neutralization of these specific principal toxins. On the other hand, the major PLA 2 fractions in $H$. curtus venom lacked lethal activity; however, the potential myotoxic properties of the various PLA $_{2}$ isoforms deserve further investigation in the future. On the whole, the sea snake venoms appeared to share similarities in their profiles and toxicity. In view of their relatively recent radiation and close phylogenetic relatedness, it is anticipated that substantial antigenicity is conserved among the different sea snake species. This immunological property of antigenicity sharing is medically important, as it would allow the use of SSAV (raised against the Malaysian H. schistosus venom) in cross-neutralizing the toxicity of different sea snake venoms. Earlier, in a nerve-muscle preparation, SSAV (1 unit $/ \mathrm{mL}$ ) added at $\mathrm{t}_{90}$ (time at which $90 \%$ inhibition of initial twitch height occurred) was able to reverse the inhibition of twitches (20-50\%) produced by H. curtus venom [24]. In agreement with the in vitro findings, the present study further confirmed that SSAV was effective in vivo in cross-neutralizing the lethality of the Malaysian H. curtus venom. The normalized potency of SSAV against $H$. curtus $(\mathrm{P}=9.35 \mathrm{mg} / \mathrm{g})$ was in fact much higher than the previously reported potencies for H. schistosus $(\mathrm{P}=2.21 \mathrm{mg} / \mathrm{g})$ [25] and Laticauda colubrina $(\mathrm{P}=5.01 \mathrm{mg} / \mathrm{g})$ [19]. This could be due to the higher $\mathrm{LD}_{50}$ of $H$. curtus venom - at a challenge dose of $5 \mathrm{LD}_{50}$, the neutralization could be interpreted as having more venom proteins being neutralized per unit antivenom. When examining the specific principal toxins, it was found that SSAV potency in neutralizing SNTX did not differ markedly among H. schistosus, H. curtus and L. colubrina (n-P $=1.2-1.5 \mathrm{mg} / \mathrm{g})[19,25]$. The neutralization of LNTX, however, varied to some extent (normalized potency was approximately $2-6 \mathrm{mg} / \mathrm{g}$ ) among these species. The finding implies a conserved repertoire of SNTX epitopes among the species. The LNTX epitopes, on the other hand, seemed to be more variable, and the potency level of neutralization followed the homology of H. schistosus $>$ H. curtus $>$ L. colubrina. On toxin-specific neutralization, it is evident that SSAV exhibited better neutralization against LNTX than SNTX, indicating that SNTX is a limiting factor of antivenom efficacy. This phenomenon has also been reported in the neutralization of 
alpha-neurotoxins of several Naja cobra species (by cobra antivenoms) [25,30,31]. Further research is needed for the improvement of elapid antivenom formulation through strategies that aim to enhance the toxin immunogenicity and broaden the species coverage in the region [23].

The sharing of protein antigens between $H$. curtus and H. schistosus is further supported by the comparable immunoreactivity of SSAV toward both venoms. As the core hydrophids are a group of relatively young marine radiation of the elapids [3], the extent of amino acid substitution/divergence and protein neofunctionalization might be rather limited within the clade, hence the highly conserved protein antigenicity. The strong immunoreactivity of SSAV toward the venom of N. scutatus (Australian tiger snake), however, is inconsistent with the very different venom compositions (proteomes) between $N$. scutatus and H. schistosus $[12,44]$. The phenomenon could be partly explained by the fact that $N$. scutatus venom was included in the immunogen mix as a strategy to enhance the anti-titer level in SSAV production [44]. This observed strong immunoreactivity also supported the cross-neutralization of N. scutatus venom toxicity by SSAV previously [44]. On fraction-based ELISA, the strong binding of $\mathrm{PLA}_{2}$ and SNTX by SSAV indicates that the anti-titer against these proteins was high, presumably due to the higher abundance of these toxins in the venom (collectively $>90 \%$ of total proteins) used in immunization. Although SSAV neutralized LNTX more effectively than it neutralized SNTX, SSAV exhibited stronger immunoreactivity toward SNTX than to LNTX. This conflicting observation implies that the immunological binding activity of antivenom to toxins does not necessarily always correlate with the in vivo neutralization activity of antivenom. Hence, the neutralization capability and potency of antivenom against specific toxins should be tested in vivo in addition to in vitro immunological assays when studying antivenomics [45,46].

\section{Conclusions}

The venom proteome of Malaysian (Penang) H. curtus shows a minimalistic toxin arsenal that is dominated by PLA 2 and 3FTX (composed of only short and long alpha-neurotoxins). The highly streamlined venom protein repertoire of the various Hydrophis sp. illustrates the case of molecular economy of toxins, which is an evolutionary solution convergently adopted by various sea snake taxa (including Laticaudinae) in response to the need for a fast moving, fish-based diet in the marine habitat. In comparison with the other marine/semi-marine species, $H$. curtus venom is unique, as there are more abundant and more diverse PLA $_{2}$ than 3 FTX (at a ratio of $\sim 3: 1$ ) in the proteome. The major toxin distribution accounts for the higher $\mathrm{LD}_{50}$ of the venom, as its toxicity is mainly driven by the short alpha-neurotoxins (the diverse PLA 2 were non-lethal). Subproteomic toxin variability within $H$. curtus of allopatric populations is apparent. The 3FTX of Malaysian H. curtus venom (Penang) comprised of mainly short neurotoxin, whereas the Australian specimens (Weipa) had more long-chain neurotoxins. The venom protein antigenicity was well conserved between $H$. curtus and the phylogenetically related H. schistosus (and Notechis scutatus) used in the production of SSAV, rendering the antivenom able to immunorecognize and in vivo cross-neutralize $H$. curtus venom effectively. The weak neutralization of short neurotoxin remains a limiting factor of antivenom efficacy in neutralization. Optimizing the immunogen formulation of alpha-neurotoxins may improve the efficacy of antivenom to neutralize NTX-predominating snake venoms.

\section{Materials and Methods}

\subsection{Samples and Chemicals}

Hydrophis curtus venom was a pooled sample from 10 adult snakes collected in the waters of Penang Island (Malaysia). The antivenom tested was Sea Snake Antivenom (SSAV) produced by CSL Ltd. (Melbourne, Australia, Seqirus Ltd. currently). The antivenom was in (liquid form) contained $\mathrm{F}\left(\mathrm{ab}^{\prime}\right)_{2}$ from horses hyperimmunized against the venoms of Hydrophis schistosus (beaked sea snake, obtained from the waters of Penang Island, Malaysia) and the Australian Notechis scutatus (common 
tiger snake). The protein concentration of the antivenom was $217.2 \pm 3.0 \mathrm{mg} / \mathrm{mL}$, determined in a previous study from the laboratory [25].

The chemicals and reagents used were primarily supplied by Sigma-Aldrich (Saint Louis, MO, USA) and were of analytical grade. The molecular weight marker Spectra ${ }^{\mathrm{TM}}$ Multicolor Broad Range Protein Ladder (10-260 kDa), trypsin (mass spectrometry grade), HPLC grade acetonitrile (ACN) and trifluoroacetic acid (TFA) were purchased from Thermo Scientific ${ }^{\mathrm{TM}}$ Pierce $^{\mathrm{TM}}$ (Waltham, MA, USA). Millipore ZipTip ${ }^{\circledR} \mathrm{C}_{18}$ Pipette Tips and LiChrospher ${ }^{\circledR}$ WP 300 RP-18 $(5 \mu \mathrm{m})$ were supplied by Merck (Burlington, MA, USA).

\subsection{Reverse-Phase High Performance Liquid Chromatography}

Two milligrams of H. curtus venom were reconstituted in MilliQ ultrapure water and fractionated using a reverse-phase column (LiChrospher ${ }^{\circledR}$ WP $300 \mathrm{C}_{18}$ column, Merck Millipore, Burlington, MA, USA) via a high performance liquid chromatography system (Shimadzu LC-20AD, Shimadzu, Tokyo, Japan). The flow rate of mobile phase was set to $1 \mathrm{~mL} / \mathrm{min}$ over a course of $180 \mathrm{~min}$. Stepwise linear gradients of mobile phase composed of $0.1 \%$ TFA in water (Solvent A) and $0.1 \%$ TFA in $100 \%$ ACN (Solvent B) were used for protein elution as follow: 0-5\% B for $10 \mathrm{~min}, 5-15 \%$ B for $20 \mathrm{~min}, 15-45 \%$ B for $120 \mathrm{~min}$ and $45-70 \%$ B over $20 \mathrm{~min}$. The elution of protein was monitored at $215 \mathrm{~nm}$. The protein fractions were collected manually, lyophilized and stored at $-20^{\circ} \mathrm{C}$ until use.

\subsection{Sodium Dodecyl Sulphate-Polyacrylamide Gel Electrophoresis (SDS-PAGE)}

The freeze-dried protein fractions collected from C18 reverse-phase HPLC were dissolved in MilliQ ultrapure water and further fractionated by electrophoresis on a $15 \%$ gel under reducing conditions. Coomassie Brilliant Blue stained the protein bands in each HPLC fractions on the gel. Spectra ${ }^{\mathrm{TM}}$ Multicolor Broad Range Protein Ladder (10 to $260 \mathrm{kDa}$ ) served as a standard for calibrating molecular weights of proteins.

\subsection{In-Solution Protein Digestion with Trypsin}

Fractionated proteins collected from the reverse-phase were reduced by DTT (Dithiothreitol), alkylated with IAA (iodoacetamide) and subjected to in-solution proteolytic digestion with trypsin according to the method reported previously [47]. Millipore ZipTip ${ }^{\circledR} \mathrm{C}_{18}$ Pipette Tips (Merck, Burlington, MA, USA) were used to clean up and desalt the trypsin-digested peptides for an enhanced performance of mass spectrometry analysis.

\subsection{Nano-ESI-LCMS/MS of the Tryptic Digests and Label-Free LCMS/MS Protein Quantitation}

The digested and desalted H. curtus venom peptides were analyzed using a nano-ESI LCMS/MS system (Agilent 1200 HPLC-Chip/MS Interface coupled with Agilent 6520 Accurate-Mass Q-TOF LC/MS, Agilent Technologies, Palo Alto, CA, USA). The peptides were loaded in a $300 \AA \mathrm{C}_{18}$, enrichment column (injection volume $=1 \mu \mathrm{L}$ ) followed by a $75 \mu \mathrm{m} \times 150 \mathrm{~mm}$ analytical column (Agilent $\mathrm{N}^{\circ}$ G4240-62010). 0.1\% formic acid in water (A) and 90\% acetonitrile in water with $0.1 \%$ formic acid (B) were used for elution of the peptides at the following stepwise linear gradients: $3-50 \%$ B for $30 \mathrm{~min}, 50-95 \%$ B for $2 \mathrm{~min}$, and $95 \%$ B for $5 \mathrm{~min}$. The ion polarity was set to positive ionization mode. The temperature of the drying gas was $325{ }^{\circ} \mathrm{C}$ and the flow rate was $5 \mathrm{~L} / \mathrm{min}$. The fragmentor voltage and capillary voltage were set to $175 \mathrm{~V}$ and $1995 \mathrm{~V}$, respectively. The ion spectra were acquired in an MS/MS mode where a MS scan range of 110-3000 m/ $z$ and a MS/MS scan range of 50-3000 m/ $z$ were used. Precursor charges were selected based on double- and triple-charged states but excluding the reference ions i.e., $922.0098 \mathrm{~m} / \mathrm{z}(\mathrm{z}=1)$ and $121.0509(\mathrm{z}=1)$. Data within the $\mathrm{MH}^{+}$mass range of 600-4000 Da was obtained and processed with Agilent Spectrum Mill MS Proteomics Workbench software packages. A single modification was selected for the carbamidomethylation of cysteine. The peptide masses were searched against a non-redundant protein sequence database from NCBI (taxonomy: Serpentes, taxid: 8570) and an in-house transcriptomic database comprising elapid species 
of Hydrophis curtus, Hydrophis schistosus, Ophiophagus hannah, Calliophis intestinalis, Bungarus caeruleus and Naja naja. The identification of protein was validated using the following parameters: protein score $>11$, peptides score $>6$, scored peak intensity (SPI) $>60 \%$. The protein abundances were estimated through HPLC and ESI-LCMS/MS as previously described [47,48]. In brief, the relative abundance of an individual protein within a chromatographic fraction was estimated by its relative spectral intensity from LCMS/MS. The protein's relative abundance in term of percentage of total venom proteins was then determined by multiplying its relative spectral intensity and its chromatographic peak area under the curve (AUC), as described previously.

\subsection{Median Lethal Dose of Venom/Toxin and Efficacy of Neutralization by Antivenom}

The venom proteins were injected intravenously into ICR mice via tail vein (20-25 g, $n=4$ per dose, 4 doses). The mice were monitored and allowed free access to food and water ad libitum. The survival ratio of mice was recorded at $24 \mathrm{~h}$. Neutralization assay was conducted as described previously [48]. A challenge dose of the venom proteins at $5 \mathrm{LD}_{50}$ was mixed with various doses of Sea Snake Antivenom (SSAV) in normal saline and pre-incubated at $37^{\circ} \mathrm{C}$ for $30 \mathrm{~min}$, followed by tail vein injection (20-25 g, $n=4$ per dose, 4 doses). The mice were allowed access to food and water ad libitum and the survival ratio was recorded at $24 \mathrm{~h}$. Animal experiments were conducted according to the CIOMS guidelines [49]. Ethics clearance was given by the Institutional Animal Care and Use Committee, Faculty of Medicine, University of Malaya (Ethical approval code: 2016-190607/TCH/R/PHARM, Date of approval: 7 June 2016).

\subsection{Immunological and Antigenic Profiling of H. curtus Venom Fractions}

The immunoreactivity of Sea Snake Antivenom (SSAV) toward the HPLC protein fractions of $H$. curtus venom was examined using an indirect enzyme-linked immunosorbent assay (ELISA) as described previously [26]. The venoms of $H$. schistosus and N. scutatus were used as positive controls, while Calloselasma rhodostoma (Malayan pit viper) venom served as negative control. Immunoplate wells were each pre-coated with $10 \mathrm{ng}$ proteins of the venom or venom protein fractions overnight at $4{ }^{\circ} \mathrm{C}$. The plate was then flicked dry and rinsed three times with phosphate-buffered saline containing $0.5 \%$ Tween ${ }^{\circledR} 20$ (PBST). The protein concentrations of SSAV were prepared at $20 \mathrm{mg} / \mathrm{mL}$, and $100 \mu \mathrm{L}$ of SSAV in 1:900 PBST dilution was added to each pre-coated well, followed by $1 \mathrm{~h}$ incubation at room temperature. After washing the plate three times with PBST, $100 \mu \mathrm{L}$ of appropriately diluted horseradish peroxidase-conjugated anti-horse-IgG (Jackson ImmunoResearch Inc., West Grove, PA, USA) in PBST (1:10000) was added to the well, followed by $1 \mathrm{~h}$ incubation at room temperature. The excess residues were washed away with PBST then. One hundred microliters of substrate solution $(0.5 \mathrm{mg} / \mathrm{mL}$ o-phenylenediamine and $0.003 \%$ hydrogen peroxide in $0.1 \mathrm{M}$ citrate-phosphate buffer, $\mathrm{pH}$ 5.0) was freshly prepared and added to each well. The enzymatic reaction took place in the dark for $30 \mathrm{~min}$ at room temperature. The reaction was then terminated by adding $50 \mu \mathrm{L}$ of $12.5 \%$ sulphuric acid, and the absorbance at $490 \mathrm{~nm}$ was read against the blank using a multiplate reader (Molecular Devices-VersaMax $^{\mathrm{TM}}$, Sunnyvale, CA, USA). Values were means \pm standard error mean (SEM) of triplicate experiments.

\subsection{Statistical Analyses}

The median lethal dose $\left(\mathrm{LD}_{50}\right)$, median effective dose $\left(\mathrm{ED}_{50}\right.$, the amount of reconstituted antivenom in $\mu \mathrm{L}$ that protects $50 \%$ of the animals tested), effective dose ratio (ER $\mathrm{E}_{50}$, the amount of venom in mg neutralized per $\mathrm{mL}$ antivenom at which $50 \%$ of envenomed mice survived) and the $95 \%$ confidence intervals (C.I.) were calculated using the Probit analysis [50]. The potency of antivenom ( $\mathrm{P}$, defined as the amount of venom or toxin completely neutralized by a unit volume of antivenom, $\mathrm{mg} / \mathrm{mL}$ ), and the normalized potency values (n-P, defined as the amount of venom or toxin completely neutralized by a unit amount of antivenom, $\mathrm{mg} / \mathrm{g}$ ) were determined according to 
Tan et al. [51]. The statistical analysis package used was the BioStat analysis software (2008 v5.2.5, AnalystSoft Inc., Vancouver, BC, Canada).

Supplementary Materials: The following is available online at http:/ /www.mdpi.com/2072-6651/11/1/3/s1, Table S1: Mass spectrometry results of venom from Hydrophis curtus (Penang, Malaysia).

Author Contributions: Conceptualization, C.H.T. and K.Y.T.; Data curation, C.H.T.; Formal analysis, C.H.T. and K.Y.T.; Funding acquisition, K.Y.T., C.H.T. and N.H.T.; Investigation, C.H.T., K.Y.T. and T.S.N.; Methodology, C.H.T. and K.Y.T.; Project administration, C.H.T.; Resources, C.H.T., S.M.S. and N.H.T.; Supervision, S.M.S. and N.H.T.; Validation, C.H.T., K.Y.T. and T.S.N.; Writing—original draft, C.H.T.; Writing—review \& editing: C.H.T., K.Y.T., T.S.N., S.M.S. and N.H.T.

Funding: This research was funded by research grants RF007C-2018 and GPF009C-2018 from the University of Malaya.

Acknowledgments: The authors are grateful for Evan SH Quah and CH Tan for sharing sea snake images.

Conflicts of Interest: The authors declare no conflict of interest.

\section{References}

1. Slowinski, J.B.; Keogh, J.S. Phylogenetic relationships of elapid snakes based on cytochrome b mtDNA sequences. Mol. Phylogenet. Evol. 2000, 15, 157-164. [CrossRef] [PubMed]

2. Sanders, K.L.; Lee, M.S.; Leys, R.; Foster, R.; Keogh, J.S. Molecular phylogeny and divergence dates for Australasian elapids and sea snakes (hydrophiinae): Evidence from seven genes for rapid evolutionary radiations. J. Evol. Biol. 2008, 21, 682-695. [CrossRef] [PubMed]

3. Sanders, K.L.; Lee, M.S.; Mumpuni; Bertozzi, T.; Rasmussen, A.R. Multilocus phylogeny and recent rapid radiation of the viviparous sea snakes (Elapidae: Hydrophiinae). Mol. Phylogenet. Evol. 2013, 66, 575-591. [CrossRef] [PubMed]

4. Reid, H.A. Epidemiology of sea-snake bites. J. Trop. Med. Hyg. 1975, 78, 106-113.

5. Reid, H.A.; Lim, K.J. Sea-snake bite; a survey of fishing villages in northwest Malaya. Br. Med. J. 1957, 2, 1266-1272. [CrossRef] [PubMed]

6. Kularatne, S.A.; Hettiarachchi, R.; Dalpathadu, J.; Mendis, A.S.; Appuhamy, P.D.; Zoysa, H.D.; Maduwage, K.; Weerasinghe, V.S.; de Silva, A. Enhydrina schistosa (Elapidae: Hydrophiinae) the most dangerous sea snake in Sri Lanka: Three case studies of severe envenoming. Toxicon 2014, 77, 78-86. [CrossRef]

7. Vithanage, K.K.; Thirumavalavan, K. A case of a sea snake bite resulting in fatal envenoming. Ceylon Med. J. 2012, 57, 174-175. [CrossRef]

8. Cao, N.; Tao, N.T.; Moore, A.; Montoya, A.; Rasmussen, A.R.; Broad, K.; Voris, H.K.; Takacs, Z. Sea Snake Harvest in the Gulf of Thailand. Conserv. Biol. 2014, 28, 1677-1687. [CrossRef]

9. WHO. Guidelines for the Management of Snake Bites; Regional office for South-East Asia: New Delhi, India, 2016.

10. Reid, H.A. Symptomatology, Pathology and Treatment of the Bites of Sea Snakes. In Snake Venoms; Lee, C.-Y., Ed.; Springer: Berlin/Heidelberg, Germany, 1979; Volume 52, pp. 922-955.

11. Gopalakrishnakone, P.; Ponraj, D.; Thwinn, M.M. Myotoxic Phospholipases from Snake Venoms: General Myoglobinuric and Local Myonecrotic Toxins; John Wiley and Sons: New York, NY, USA, 1997.

12. Tan, C.H.; Tan, K.Y.; Lim, S.E.; Tan, N.H. Venomics of the beaked sea snake, Hydrophis schistosus: A minimalist toxin arsenal and its cross-neutralization by heterologous antivenoms. J. Proteom. 2015, 126, 121-130. [CrossRef]

13. Brook, G.A.; Torres, L.F.; Gopalakrishnakone, P.; Duchen, L.W. Effects of phospholipase of Enhydrina schistosa venom on nerve, motor end-plate and muscle of the mouse. Q. J. Exp. Physiol. 1987, 72, 571-591. [CrossRef]

14. Mackessy, S.P.; Tu, A.T. Biology of the sea snakes and biochemistry of their venoms. In Toxin-Related Diseases: Poisons Originating from Plants, Animals and Spoilage; Tu, A.T., Ed.; Oxford \& IBH Publishing Co.: New Delhi, India, 1993; pp. 305-351.

15. Fry, B.G.; Wuster, W.; Ryan Ramjan, S.F.; Jackson, T.; Martelli, P.; Kini, R.M. Analysis of Colubroidea snake venoms by liquid chromatography with mass spectrometry: Evolutionary and toxinological implications. Rapid Commun. Mass Spectrom. 2003, 17, 2047-2062. [CrossRef] [PubMed] 
16. Calvete, J.J.; Ghezellou, P.; Paiva, O.; Matainaho, T.; Ghassempour, A.; Goudarzi, H.; Kraus, F.; Sanz, L.; Williams, D.J. Snake venomics of two poorly known Hydrophiinae: Comparative proteomics of the venoms of terrestrial Toxicocalamus longissimus and marine Hydrophis cyanocinctus. J. Proteom. 2012, 75, 4091-4101. [CrossRef] [PubMed]

17. Lomonte, B.; Pla, D.; Sasa, M.; Tsai, W.C.; Solorzano, A.; Urena-Diaz, J.M.; Fernandez-Montes, M.L.; Mora-Obando, D.; Sanz, L.; Gutierrez, J.M.; et al. Two color morphs of the pelagic yellow-bellied sea snake, Pelamis platura, from different locations of Costa Rica: Snake venomics, toxicity, and neutralization by antivenom. J. Proteom. 2014, 103, 137-152. [CrossRef] [PubMed]

18. Laustsen, A.H.; Gutierrez, J.M.; Rasmussen, A.R.; Engmark, M.; Gravlund, P.; Sanders, K.L.; Lohse, B.; Lomonte, B. Danger in the reef: Proteome, toxicity, and neutralization of the venom of the olive sea snake, Aipysurus laevis. Toxicon 2015, 107, 187-196. [CrossRef]

19. Tan, C.H.; Wong, K.Y.; Tan, K.Y.; Tan, N.H. Venom proteome of the yellow-lipped sea krait, Laticauda colubrina from Bali: Insights into subvenomic diversity, venom antigenicity and cross-neutralization by antivenom. J. Proteom. 2017, 166, 48-58. [CrossRef]

20. Neale, V.; Sotillo, J.; Seymour, J.E.; Wilson, D. The venom of the spine-bellied sea snake (Hydrophis curtus): Proteome, Toxin diversity and intraspecific variation. Int. J. Mol. Sci. 2017, 18, 2695. [CrossRef]

21. Pahari, S.; Bickford, D.; Fry, B.G.; Kini, R.M. Expression pattern of three-finger toxin and phospholipase $\mathrm{A}_{2}$ genes in the venom glands of two sea snakes, Lapemis curtus and Acalyptophis peronii: Comparison of evolution of these toxins in land snakes, sea kraits and sea snakes. BMC Evol. Biol. 2007, 7, 175. [CrossRef]

22. Takasaki, C.; Kimura, S.; Kokubun, Y.; Tamiya, N. Isolation, properties and amino acid sequences of a phospholipase $\mathrm{A}_{2}$ and its homologue without activity from the venom of a sea snake, Laticauda colubrina, from the Solomon Islands. Biochem. J. 1988, 253, 869-875. [CrossRef]

23. Ratanabanangkoon, K.; Tan, K.Y.; Eursakun, S.; Tan, C.H.; Simsiriwong, P.; Pamornsakda, T.; Wiriyarat, W.; Klinpayom, C.; Tan, N.H. A simple and novel strategy for the production of a pan-specific antiserum against Elapid snakes of Asia. PLoS Negl. Trop. Dis. 2016, 10, e0004565. [CrossRef]

24. Chetty, N.; Du, A.; Hodgson, W.C.; Winkel, K.; Fry, B.G. The in vitro neuromuscular activity of Indo-Pacific sea-snake venoms: Efficacy of two commercially available antivenoms. Toxicon 2004, 44, 193-200. [CrossRef]

25. Tan, K.Y.; Tan, C.H.; Fung, S.Y.; Tan, N.H. neutralization of the principal toxins from the venoms of Thai Naja kaouthia and Malaysian Hydrophis schistosus: Insights into toxin-specific neutralization by two different antivenoms. Toxins 2016, 8, 86. [CrossRef] [PubMed]

26. Tan, C.H.; Tan, N.H.; Tan, K.Y.; Kwong, K.O. Antivenom cross-neutralization of the venoms of Hydrophis schistosus and Hydrophis curtus, two common sea snakes in Malaysian waters. Toxins 2015, 7, 572-581. [CrossRef] [PubMed]

27. Tan, C.H.; Tan, K.Y.; Tan, N.H. A Protein Decomplexation strategy in snake venom proteomics. Methods Mol. Biol. 2019, 1871, 83-92. [CrossRef] [PubMed]

28. Tan, K.Y.; Tan, C.H.; Sim, S.M.; Fung, S.Y.; Tan, N.H. Geographical venom variations of the Southeast Asian monocled cobra (Naja kaouthia): Venom-induced neuromuscular depression and antivenom neutralization. Comp. Biochem. Physiol. C Toxicol. Pharmacol. 2016, 185-186, 77-86. [CrossRef] [PubMed]

29. Barber, C.M.; Isbister, G.K.; Hodgson, W.C. Alpha neurotoxins. Toxicon 2013, 66, 47-58. [CrossRef] [PubMed]

30. Tan, N.H.; Wong, K.Y.; Tan, C.H. Venomics of Naja sputatrix, the Javan spitting cobra: A short neurotoxin-driven venom needing improved antivenom neutralization. J. Proteom. 2017, 157, 18-32. [CrossRef] [PubMed]

31. Wong, K.Y.; Tan, C.H.; Tan, N.H. Venom and Purified Toxins of the Spectacled Cobra (Naja naja) from Pakistan: Insights into Toxicity and Antivenom Neutralization. Am. J. Trop. Med. Hyg. 2016, 94, 1392-1399. [CrossRef] [PubMed]

32. Wong, K.Y.; Tan, C.H.; Tan, K.Y.; Quraishi, N.H.; Tan, N.H. Elucidating the biogeographical variation of the venom of Naja naja (spectacled cobra) from Pakistan through a venom-decomplexing proteomic study. J. roteom. 2018, 175, 156-173. [CrossRef] [PubMed]

33. Oh, A.M.F.; Tan, C.H.; Ariaranee, G.C.; Quraishi, N.; Tan, N.H. Venomics of Bungarus caeruleus (Indian krait): Comparable venom profiles, variable immunoreactivities among specimens from Sri Lanka, India and Pakistan. J. Proteom. 2017, 164, 1-18. [CrossRef] 
34. Tan, K.Y.; Liew, J.L.; Tan, N.H.; Quah, E.S.H.; Ismail, A.K.; Tan, C.H. Unlocking the secrets of banded coral snake (Calliophis intestinalis, Malaysia): A venom with proteome novelty, low toxicity and distinct antigenicity. J. Proteom. 2018. [CrossRef]

35. Lomonte, B.; Rey-Suarez, P.; Fernandez, J.; Sasa, M.; Pla, D.; Vargas, N.; Benard-Valle, M.; Sanz, L.; Correa-Netto, C.; Nunez, V.; et al. Venoms of Micrurus coral snakes: Evolutionary trends in compositional patterns emerging from proteomic analyses. Toxicon 2016, 122, 7-25. [CrossRef] [PubMed]

36. Doley, R.; Zhou, X.; Kini, R.M. Snake Venom Phospholipase $A_{2}$ Enzymes; CRC Press: Boca Raton, FL, USA, 2009.

37. Geh, S.L.; Toh, H.T. Ultrastructural changes in skeletal muscle caused by a phospholipase A2 fraction isolated from the venom of a sea snake, Enhydrina schistosa. Toxicon 1978, 16, 633-643. [CrossRef]

38. Tan, K.Y.; Tan, C.H.; Chanhome, L.; Tan, N.H. Comparative venom gland transcriptomics of Naja kaouthia (monocled cobra) from Malaysia and Thailand: Elucidating geographical venom variation and insights into sequence novelty. PeerJ 2017, 5, e3142. [CrossRef] [PubMed]

39. Tan, C.H.; Tan, K.Y.; Fung, S.Y.; Tan, N.H. Venom-gland transcriptome and venom proteome of the Malaysian king cobra (Ophiophagus hannah). BMC Genom. 2015, 16, 687. [CrossRef] [PubMed]

40. Yamazaki, Y.; Morita, T. Structure and function of snake venom cysteine-rich secretory proteins. Toxicon 2004, 44, 227-231. [CrossRef] [PubMed]

41. Heyborne, W.H.; Mackessy, S.P. Cysteine-rich secretory proteins in reptile venoms. In Handbook of Venoms and Toxins of Reptiles; Mackessy, S.P., Ed.; CRC Press: Boca Raton, FL, USA, 2009; pp. 325-336.

42. Tan, C.H.; Tan, N.H. Toxinology of Snake Venoms: The Malaysian Context. In Snake Venoms; Gopalakrishnakone, P., Inagaki, H., Mukherjee, A.K., Rahmy, T.R., Vogel, C.-W., Eds.; Springer: Dordrecht, The Netherlands, 2015; pp. 1-37. [CrossRef]

43. Tan, N.H.; Ponnudurai, G. A comparative study of the biological properties of some sea snake venoms. Comp. Biochem. Physiol. B 1991, 99, 351-354. [CrossRef]

44. Tan, C.H.; Tan, K.Y.; Tan, N.H. Revisiting Notechis scutatus venom: On shotgun proteomics and neutralization by the "bivalent" Sea Snake Antivenom. J. Proteom. 2016, 144, 33-38. [CrossRef]

45. Gutiérrez, J.M.; Lomonte, B.; León, G.; Alape-Girón, A.; Flores-Díaz, M.; Sanz, L.; Angulo, Y.; Calvete, J.J. Snake venomics and antivenomics: Proteomic tools in the design and control of antivenoms for the treatment of snakebite envenoming. J. Proteom. 2009, 72, 165-182. [CrossRef]

46. Faisal, T.; Tan, K.Y.; Sim, S.M.; Quraishi, N.; Tan, N.H.; Tan, C.H. Proteomics, functional characterization and antivenom neutralization of the venom of Pakistani Russell's viper (Daboia russelii) from the wild. J. Proteom. 2018, 183, 1-13. [CrossRef]

47. Tan, C.H.; Tan, K.Y.; Yap, M.K.; Tan, N.H. Venomics of Tropidolaemus wagleri, the sexually dimorphic temple pit viper: Unveiling a deeply conserved atypical toxin arsenal. Sci. Rep. 2017, 7, 43237. [CrossRef]

48. Tan, C.H.; Liew, J.L.; Tan, K.Y.; Tan, N.H. Assessing SABU (Serum Anti Bisa Ular), the sole Indonesian antivenom: A proteomic analysis and neutralization efficacy study. Sci. Rep. 2016, 6, 37299. [CrossRef] [PubMed]

49. Howard-Jones, N. A CIOMS ethical code for animal experimentation. WHO Chron 1985, 39, 51-56. [PubMed]

50. Finney, D.J. Probit Analysis, 2nd ed.; Cambridge University Press: Cambridge, UK, 1952.

51. Tan, K.Y.; Tan, N.H.; Tan, C.H. Venom proteomics and antivenom neutralization for the Chinese eastern Russell's viper, Daboia siamensis from Guangxi and Taiwan. Sci. Rep. 2018, 8, 8545. [CrossRef] [PubMed]

(C) 2018 by the authors. Licensee MDPI, Basel, Switzerland. This article is an open access article distributed under the terms and conditions of the Creative Commons Attribution (CC BY) license (http:/ / creativecommons.org/licenses/by/4.0/). 